\title{
THE APPLICATION OF PRINCIPAL COMPONENT ANALYSIS (PCA) FOR THE STUDY OF THE SPANISH TOURIST DEMAND
}

\author{
María Jesús GonzÁlez GonzÁlez ${ }^{1}$, María-Eva Vallejo-Pascual ${ }^{2}$ \\ ${ }^{1}$ Departamento de Geografía y Geología, Facultad de Filosofía y Letras, Universidad de León, Campus de \\ Vegazana s/n, 24071, León, España. ORCID: 0000-0002-3639-3446 \\ ${ }^{2}$ Departamento de Economía y Estadística, Facultad de Ciencias Económicas y Empresariales, Universidad de \\ León, Campus de Vegazana s/n, 24071, León, España. ORCID: 0000-0001-7759-7165
}

Manuscript received: February 26, 2018

Revised version: September 18, 2018

González González M.J., Vallejo-Pascual M.-E., 2018. The application of principal component analysis (PCA) for the study of the Spanish tourist demand. Quaestiones Geographicae 37(4), Bogucki Wydawnictwo Naukowe, Poznań, pp. 43-52. 2 tables, 3 figs.

\begin{abstract}
The objective of this study is the characterisation of the Spanish autonomous communities as tourist destinations for Spanish trips, based on the activities carried out, using the principal component method. The Spanish tourist is not only motivated by the sun and beach. This paper aims to clarify how Spanish people consider other tourist destinations. We contrast how frequently other types of tourism are valued when choosing their destination within the Spanish geography. Inland tourism, sports tourism, entertainment as well as gastronomy are becoming increasingly important.

KEY WORDS: Spain, autonomous communities, tourist demand, principal component analysis

Corresponding author: González González, María Jesús, Departamento de Geografía y Geología, Facultad de Filosofía y Letras, Universidad de León, Campus de Vegazana s/n, 24071, León, España, e-mail: mjgong@unileon.es
\end{abstract}

\section{Introduction}

According to the World Tourism Organisation (UNWTO), tourist demand is defined as activities carried out by people travelling to and staying in places outside their usual environment for no longer than one consecutive year for leisure, business or other purposes not related to the exercise of an activity remunerated in the place visited (Rivas 2008: 11).

Very few reflections have been made on the Spanish tourist demand. In addition, there is a lack of scientific research which in fact, brings something new for advancement in this field of knowledge, as well as methodologies for its study. Barretto (2004) shows us this point of view when referring to the scientific production of tourism.

There is a lack of scientific production capable of devising new theories to help in the application of better techniques but fundamentally, to create new paradigms. For us to aspire to a new model of tourism, we need new paradigms referring to tourism itself and to society as a whole (Barretto 2004: 87).

Castrogiovanni (2007) also highlights the need for a deeper reading of the factors that motivate the human being to travel and agrees that sometimes there is a reductionist vision on tourism by scholars examining this phenomenon.

The motivating factors that cause this movement around the world are countless. Some are easily detected; others, because they involve greater subjectivity, are difficult to evaluate. Thus, it no longer seems possible for us to see tourism in a generic way, although, historically, it has been seen in several professional fields as a set of activities or financial transactions, which seems to be, at least, a reductionist approach (Castrogiovanni 2004: 14). 
It is perceived that the reflections should lead to the tourist being thought of as a historical being. On the contrary, the tourist is a "being" in continuous construction and formation. For its part, tourism is experience. It is experience at the moment in which that tourist "being" is created. The internal impressions of this action are not formed only during the journey or displacement itself, but also in the moments that anticipate the act of tourism and in the moments that continue after the tourist "being" has undertaken their journey. Likewise, the tourist experience cannot be analysed disconnected from the historical moment (Panosso Netto 2007).

The tourist space is formed by heterogeneity across the geographical space and territorial organisation. Because they are tied to capitalism, differences in the tourist space establish a hierarchy in terms of consumption. In general, the tourist space converts the territory into resources and factors at the same time. This paper aims to clarify how Spanish people's preferences have changed with regard to tourist destinations. Inland tourism has increased due to the main impulse of the European LEADER initiative. Currently, the National and Comprehensive Tourism Plan (2012-2015) recommends that governments of autonomous communities enhance their strategic plans to increase the tourist offer inland, based on quality and cultural, natural and gastronomic heritage. Communication plays an important role in the task of bringing subjects closer to the tourist space by reorganising relationships between subjects and objects (Morin 2000).

The beginning of tourism in Spain was late; its evolution is divided into three stages: the first, since the beginning of the 20th century, is known as elite tourism or prototourism, focused on spas. The second, since the 1960s, developed as sun and beach tourism or Fordist tourism. And the third, from the 1990s, inland tourism, coinciding with post modernity. Current tourism has been identified with heritage tourism as a synonym for cultural tourism (Pillet 2015: 191).

Pearce (2014: 29) has linked territories with tourism "from a perspective based more on the territorial plane, using concepts such as tourist area or tourist place, to refer to territorial elements transformed by tourism"; other authors have linked the territory with heritage, considering territorial heritage as a cultural and economic resource of the first order (Ortega Valcárcel 1998: 47). In this context, approaching the study of the tourism market from the marketing focus becomes an important competitive advantage. Therefore, beyond the theoretical models related to tourism, one of the main objectives of researchers is the development and adaptation of methodologies to the existing needs in the tourism sector that are able to provide the necessary market information. Ultimately, advancements made in the field of tourism research attempt to allow planning based on strategies in a rigorous manner (Valls 1992; Bordas, Rubio 1993; Picón, Varela 2000; Bigné, Sánchez 2001; Bigné et al. 2001; Gallarza et al. 2002; Varela et al. 2004, Varela et al. 2006; Rodríguez, Molina 2007; Rial et al. 2008, 2010; Merinero, Pulido 2009; Ferreira Lopes et al. 2010; Wilson, Hollinshead 2015; Richards 2018).

The analysis carried out in this work using the PCA method aims to contrast the following hypotheses:

1. Related to factors identified:

- Spanish tourists are not only motivated by sun and beach tourism. Inland tourism (religious vs. architectural and cultural heritage), sports tourism, entertainment (theme parks and spas), and gastronomy (increasingly important) are other aspects they value when choosing their destination within the Spanish geography.

2. Related to autonomous communities:

- the communities traditionally linked to sun and beach tourism are the Canary Islands and the Balearic Islands, therefore others such as Andalusia, Catalonia, Murcia and Valencia must qualify their "offer of sun and beach", since the traveller is looking for another type of tourist activity nowadays. On the other hand, communities on the north coast, which are always associated with bad weather, should enhance their offer of sun and beach as temperatures have been rising in recent years.

3. Other new trends in autonomous communities that were traditionally not considered as tourist destinations.

To demonstrate these assumptions, we have made an empirical analysis that has allowed us to set the basic steps to follow in order to define a system of indicators and add their information in a synthetic measure. Based on the conclusions 
drawn in this analysis, we have defined the procedures for obtaining synthetic indicators, which allow us to work with the maximum amount of information contained in the initial system and have a lower degree of subjectivity and results that are easier to interpret.

\section{Methodology}

The selected information corresponds to that in the FAMILITUR table 3.32 (2012), which can be seen in Table 1 in the attached Annex. This table is based on trips made by Spanish tourists to autonomous regions in Spain and provides information related to the activity. Each value expresses the percentage of trips to an autonomous region, presented by each touristic activity.

Multivariate statistical methods are appropriate for this type of analysis as the table in question is too large for individual analysis. Labels have been assigned to each autonomous community and activity, interchanging rows and columns, for an adequate analysis of the data. Tables 1 and 2 in the Annex show the labels corresponding to touristic activities.

The rows in the tables represent the 17Spanish autonomous regions (individuals). The first 16 columns are the active variables (main trip activities) and the last 8 are supplementary variables (sub-variables from sports). Active variables define the components extracted from the correlation matrix. Supplementary variables should be interpreted according to those components and they do not increase data variability. (Dazy, Le Barzic 1996: 20).

The Principal Component Analysis enables us to do the following:

- identify the components (relevant dimensions) related to tourist activities carried out by Spanish tourists with national destinations;

Table 1. Eigenvalues, variance percentages and cumulative percentage.

\begin{tabular}{|c|c|c|c|}
\hline Component & Eigenvalue & $\begin{array}{c}\text { Percentage } \\
\text { of variance }\end{array}$ & $\begin{array}{c}\text { Cumulative } \\
\text { percentage } \\
\text { of variance }\end{array}$ \\
\hline 1 & 6.111 & 38.2 & 38.2 \\
\hline 2 & 3.431 & 21.4 & 59.6 \\
\hline 3 & 1.916 & 12.0 & 71.6 \\
\hline 4 & 1.149 & 7.2 & 78.8 \\
\hline
\end{tabular}

Source: own study.
- characterise the individuals analysed (Spanish autonomous communities) with respect to the previously identified components;

- detect minority trends in variables or individuals that are not very prominent.

The development of the PCA theoretical method can be found in Hair et al. (1999: 79-140), in Uriel and Aldá (2005: 365-406) and Anderson (2004). Based on the numerical and graphical results we can make conclusions on the variables and individuals, which would not be possible from a simple observation of the original data table. The main results are:

- factor loadings: provide meaning to each component (or factor), according to the original active variables;

- correlation circles (plots of two-dimensional variables): allow the identification of those active variables influenced by both components (factors) of each plane;

- individual scatter plots (two-dimensional individual plots): allow for the description of individuals according to the meaning of the components (factors) of each plane.

\section{Empirical results}

All the statistical results (graphs and tables) were obtained with Coheris SPAD 9. The study carried out presents a time limitation because it refers to the year 2012, which was the last year available in FAMILITUR. Subsequent studies that modify this time horizon will satisfactorily complete the analysis performed.

\section{Eigenvalues, variance percentages and cumulative percentage}

Components were extracted according to the Kaiser criterion from the correlation matrix. The components with an eigenvalue higher than 1 are collected in Table 1.

As can be seen, the first 4 components explain $78.8 \%$ of the information. However, as can be observed in Table 2, the fourth component only represents high correlation with the value linked to conferences or meetings. Therefore, this study will be limited to reviewing the first three factors, which explain $71.6 \%$ of the group inertia. 


\section{Factor loadings}

Table 2 includes the active variables with high factor loadings (greater than 0.5 in the absolute value) with the fourth components retained, as well as the relevant correlations of supplementary variables.

To provide meaning to each principal component, red corresponds to those activities with significant correlation in factor 1, green in factor 2 and blue in factor 3 . Therefore, for each of the three retained factors, we highlight the following characteristics:

Factor 1 opposes beach tourism in comparison with tourism for religious purposes. According to this factor, beach tourism is correlated with activities such as going for a drink and cultural visits. Administrative procedures, gambling and visits to theme parks are other activities that often combine with the beach.

On the other side, there is a high correlation between activities related to religious tourism, correlated with the custom of visiting and staying with friends and family. A question to be determined is whether accommodation is selected beforehand, or on the contrary, its selection is just one more activity of the trip.
Supplementary activities that present high correlations are nautical sports, precisely with the extreme defined by beach activities. Therefore, this first factor can be considered as traditional tourism (coast-beach tourism vs. inland-religious tourism).

The positive side of factor 2 is correlated with sports tourism, as opposed to entertainment tourism (cultural and sports) correlated with the negative side. Taking into account other large loadings, it can be seen that activities related to health and water are related to sports tourism; on the contrary, visits of relatives (and friends) and conferences and meetings, are correlated with entertainment tourism.

Outstanding sports activities include nautical and outdoor sports, extreme sports and snow sports among those that generate more interest.

This second factor can be considered as the dimension of sports tourism $v$ s. entertainment tourism.

The positive side of factor 3 is defined by visits to theme parks, while the negative side is defined by nature tourism correlated with gastronomic activities and visits to wineries. Therefore, it is the dimension of tourism to theme parks $v s$. nature and gastronomic tourism.

Table 2. Factor loadings.

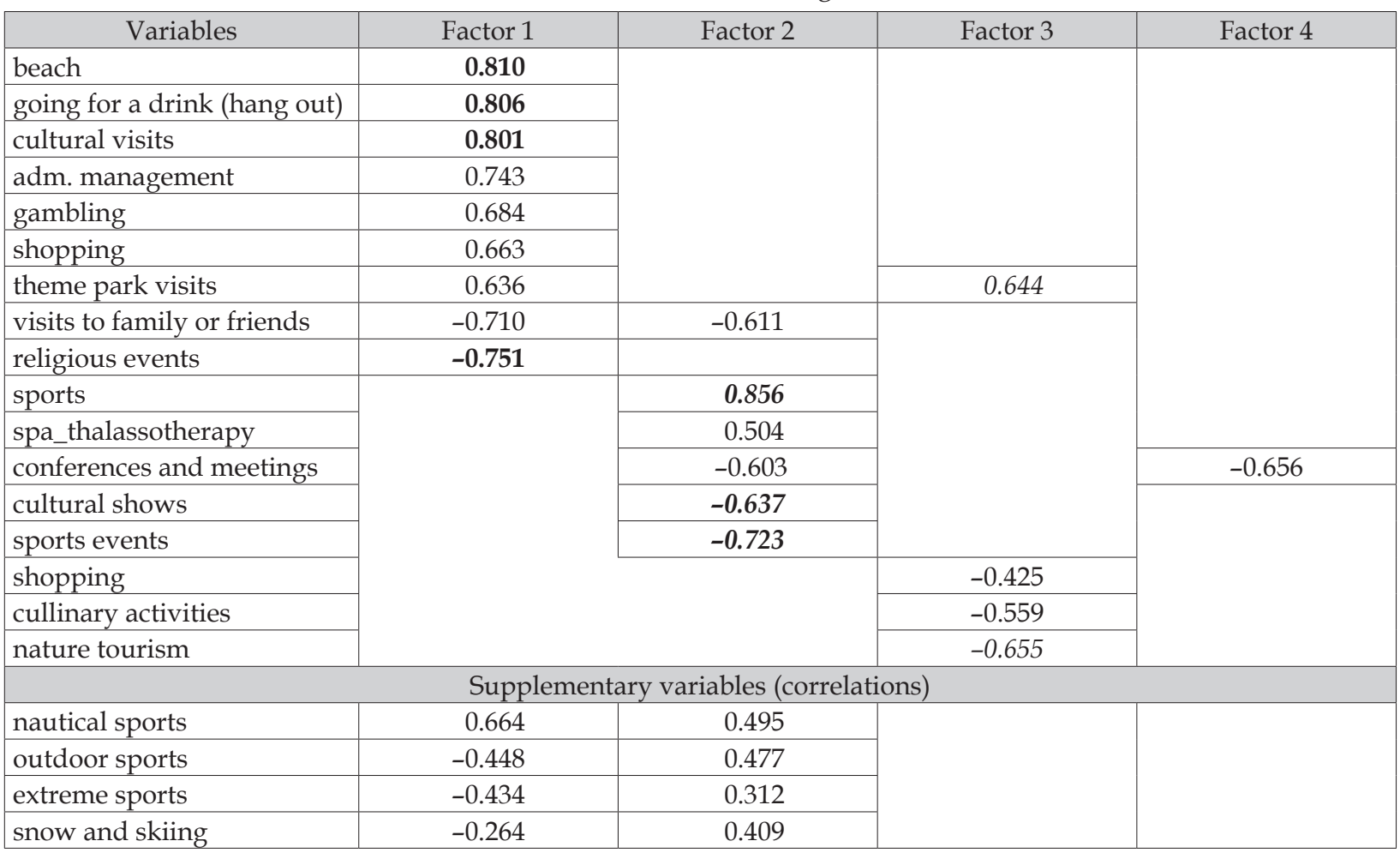

Source: own study. 


\section{Correlation circles}

The previous considerations are clarified in the correlation circles, whose colour codes are red for factor 1 and green for factor 2 .

In view of Fig. 1, the following considerations can be added to the activities analysed:

- As already noted, gambling and administrative procedures are also combined with beach destinations in many cases, as well as spa and thalassotherapy services and cultural visits. Although, while the spa and thalassotherapy are more typical of those travellers with preferences for sport, cultural visits are made by travellers with interest in cultural and sporting events, as well as among attendants at conferences and meetings.

- On the other hand, visits to theme parks are also combined with the beach, due to the fact that they are mostly located in coastal regions.

- As for gastronomic activities and shopping (together with window-shopping), they are frequent both on trips to beach destinations and those with preferences for activities such as shows and conferences, given their position in the plane between factors 1 and 2 .

- As already pointed out, visits to family and friends are frequent on trips with religious interests and among participants in conferences and meetings as well as trips with cultural

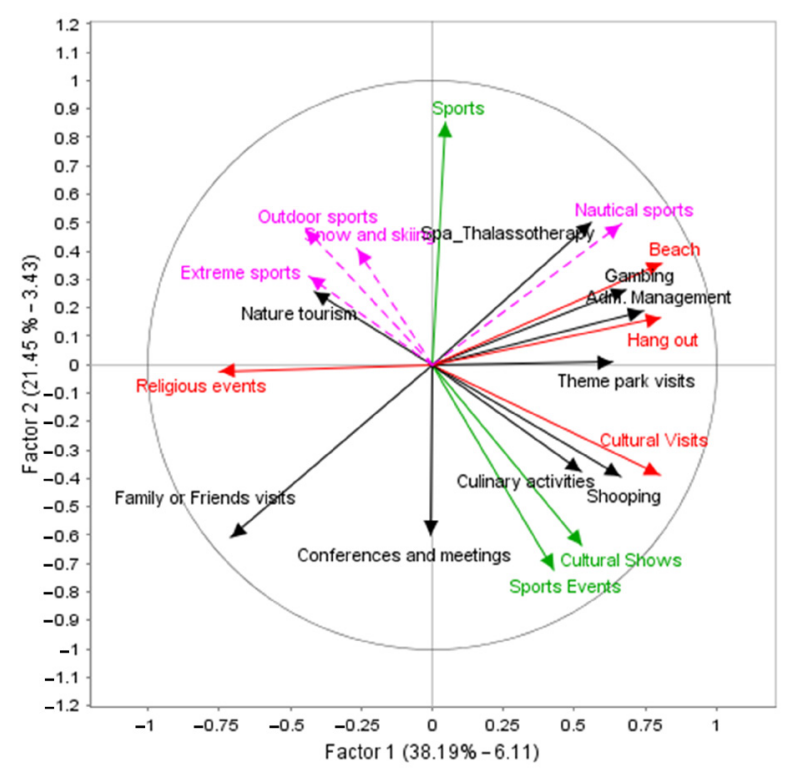

Fig. 1. First correlation circle: components 1 and 2 (first factorial plane).

Source: own study. content. However, visits to cultural places do not usually take place on trips with beach destinations or those for sports purposes.

- As expected, nautical sports are basically linked to trips with beach activities; on the other hand, outdoor sports, in addition to extreme and snow sports, are closely linked to nature tourism.

- Conferences and meetings constitute a type of trip with particular activities and interests, taking into account their position in this first factorial plane and their high correlation with factor 4 .

- When a trip is made to a theme park, it is not usual to take this opportunity to visit family and friends, or engage in nature tourism.

- In addition, nature tourism is not common on trips with a preference for the beach; although on some trips with religious interest, activities related to nature tourism are carried out.

- In addition to the aforementioned, shopping (and window shopping) is also combined with gastronomic activities, but it is not common to spend a long time shopping on nature tourism trips or trips to theme parks.

\section{Individual scatter plots}

The graph representing individuals (in this case, the Spanish autonomous communities) on the first two factorial planes is presented in Figs 2 and 3. Each individual is represented according to their relative contribution, since this shows the proportion that the plane explains for each individual. Therefore, an individual with a contribution greater than 0.5 (bigger circles) is considered well represented. The numerical results that support these graphs are included in Tables 2 and 3 in the Annex.

Observing Fig. 2, the following considerations can be made about well represented individuals:

- On the positive side of component 1, the autonomous communities traditionally identified with the sun and beach stand out: The Canary and Balearic Islands. Cantabria, and to a certain extent the Basque Country, also appear positioned in this extreme and in a much clearer way than autonomous communities traditionally identified with the sun-beach, such as Andalusia, the Community of Valencia, Murcia and Catalonia. In fact, the Community of 


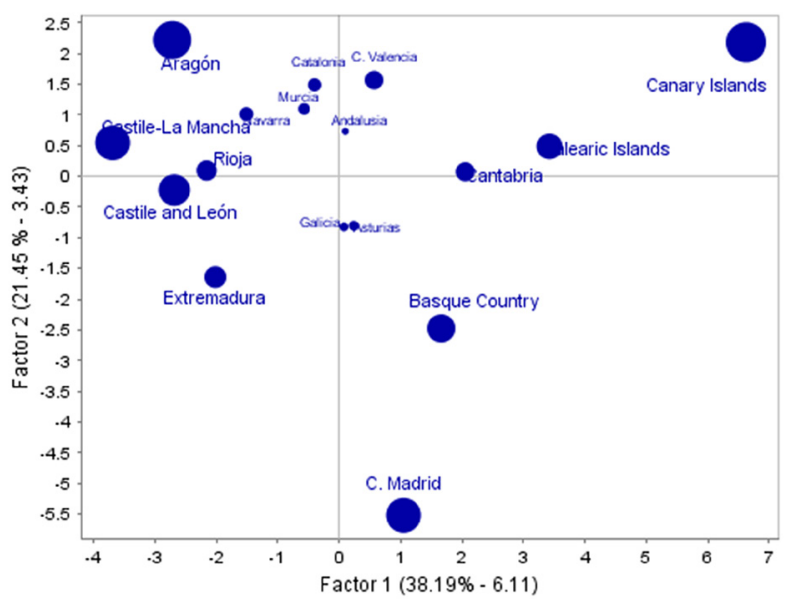

Fig. 2. Projection of the autonomous communities onto the first factorial plane.

Source: own study.

Valencia, together with Catalonia, have a central position in this factor and stand out more in the positive part of the second one, as we will discuss later. Murcia, Andalusia, Asturias and Galicia are in a central position on the graph, in addition to being poorly represented.

- Castile-La Mancha, Castile and León and Aragón appear at the negative end of factor 1 (identified with religious and indoor tourism). La Rioja and Extremadura also appear with a less prominent position at the same end.

- The positions highlighted in the positive part of component 2 (identified with sports) correspond to Aragón and the Canary Islands. Taking into account the supplementary variables in Fig. 1, Aragón is identified with snow, outdoor sports and extreme sports; and the Canary Islands with nautical sports.

- Madrid, and to a lesser extent the Basque Country, stand out at the negative end of factor 2 (identified with cultural tourism or sports shows), with an important contribution

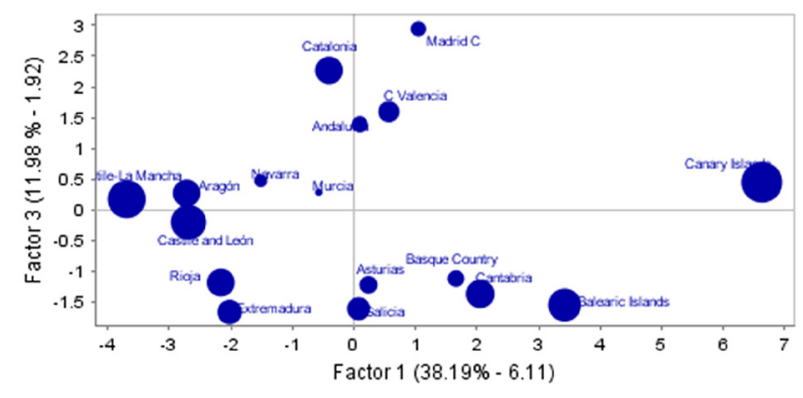

Fig. 3. Projection of the autonomous communities onto the second factorial plane.

Source: own study. of activities related to visiting relatives and friends, and conferences and meetings.

- As previously highlighted, the Basque Country and Cantabria draw some attraction for the sun and the beach taking into account their position on the positive end of the factor. Changes in position and relative contribution between Fig. 2 and Fig. 3 make it possible to add other considerations:

- The autonomous community most clearly identified with theme parks is Catalonia (on this plane it is positioned at the positive end of factor 3 and with a greater contribution than in Fig. 2). Madrid also appears in a prominent position, but its relative contribution is very low, which indicates that theme parks are only the attraction on some trips to this community.

- Regarding nature tourism, the two most attractive autonomous regions are Galicia and Cantabria (they increased their relative contribution and modified their position from the central part to the lower end of factor 3). Other communities with a certain predilection for these trips are Asturias and the Balearic Islands, but to a lesser extent, given that their changes were less relevant.

- On the other hand, La Rioja and the Basque Country particularly combine interest in nature and gastronomy in a prominent way.

- Figs 2 and 3 do not highlight any very important tourist activities for the following autonomous communities:

- Murcia and Navarra present a central position and a low relative contribution in all planes. Therefore, the dimensions identified do not adequately define the attraction for tourists to these two communities, though the position of Navarra allows relating outdoor and snow sports to a certain extent.

- Andalusia and the Community of Valencia, which increase their contribution and maximise their position in the positive part of factor 3 (Fig. 3). Therefore, the attraction for theme parks is part of their touristic interest.

- Asturias, which changes its relative contribution in Fig. 3 towards the negative end of factor 3 and therefore, shows a certain tendency to activities related to nature tourism.

- Extremadura apparently has not modified its position or its contribution between both Figures. Its position can be interpreted from 
a certain importance of religious tourism, entertainment tourism and nature tourism, but without a well-defined tourist attraction.

\section{Conclusions}

The analysis carried out has shown the preferences of Spanish travellers according to the autonomous community of destination: beach tourism, religious tourism (architectural and cultural heritage), sports tourism, entertainment tourism (cultural and/or sports), theme park tourism and nature tourism. The identification of the above can serve as a guide for administrative bodies to orientate their strategies at an autonomous community level.

Undoubtedly, beach tourism (and sun) is the main tourist preference of Spanish travellers, but in clear competition with inland tourism, since both constitute the activities that define the first dimension. While the hotel infrastructure and complementary activities are clearly developed for the former (drinks, gambling, cultural tourism, and shopping, mainly), cultural and architectural heritage tourism (religious) only appears to be related to visits to family and friends. To be precise, the autonomous communities with which this tourism is identified (Castile-La Mancha, Castile and León and Aragón, mainly) could promote other types of tourism and activities, as well as the subsequent development of adequate hotel infrastructure in order to increase their tourist potential and income.

As for beach resorts, it is noteworthy that autonomous communities traditionally linked to beach tourism do not seem to be highlighted in this analysis, such as the Community of Valencia, Murcia, Andalusia and Catalonia. Possibly, these communities offer other types of activities besides the traditional sun-beach (as is the case of the theme parks in Catalonia, Community of Valencia and Andalusia), although they must take into account that in order to reinforce this type of tourism amongst Spanish people, they have to compete with the Canary Islands and the Balearic Islands, in the first place.

Sports activities are another dimension of tourism preferred by the Spanish population as opposed to entertainment activities, according to this analysis. Given the variety and geographical diversity of our country, the offer of sports is also great, although it is organised around two main types: water and snow. Activities related to the latter constitute the main activity in autonomous communities that apparently do not stand out in other dimensions, such as Aragón and, to a lesser extent, Navarra. Therefore, other autonomous communities such as Cantabria or Castile and León must define their offer in winter sports to be able to compete with those mentioned (they have potential but it is not sufficiently developed). Regarding water sports, it is the Canary Islands and also the Balearic Islands which clearly stand out; an issue to be taken into account by other communities that try to promote this type of tourism.

As for entertainment tourism (cultural and sports), Madrid is clearly the leading community, together with the Basque Country. Activities carried out within the framework of conferences and meetings have also been identified as one of the dimensions with their own entity, in which the Community of Madrid and the Basque Country are clearly positioned. Perhaps it is necessary to redefine this type of activity with a greater use of cultural tourism, given that they seem to be linked clearly to the entertainment tourism (cultural and sports), and also to visits to family and friends.

Theme park tourism is an important dimension, which should be completed with another type of activity in order to make better use of its economic and tourist potential given that it is clearly diversified according to the analysis.

Nature tourism also has its own entity, mainly in autonomous regions such as Galicia and Cantabria. Although, other autonomous communities such as Asturias, Extremadura or the Balearic Islands could improve their positioning regarding this type of activity, taking into account their geographic potential.

It is surprising, considering the cultural heritage of all the autonomous communities without exception, that cultural tourism is not one of the dimensions identified in the analysis. It would be interesting to analyse the reasons, perhaps due to a loss of interest in this type of activity in favour of others that have been identified. It might be interesting to receive more attention from administrative bodies.

Neither is gastronomic and winery tourism a clearly defined dimension. This type of activity is associated with others such as nature tourism and 
in communities such as the Basque Country and La Rioja, although strengthening it could be a strategy to follow in certain autonomous communities.

\section{Acknowledgements}

This work is part of research project results CSO2015-63970-R (MINECO/FEDER), State Program of Research Excellence, Development and Innovation Challenges Oriented Society, Ministry of Economy and Competitiveness, Government of Spain.

\section{References}

Anderson T.W., 2004. An introduction to multivariate statistical analysis. John Wiley and Sons, Inc., New York.

Barretto M., 2004. Produção científica na área de turismo. In: Moesch M.M., Gastal S., (orgs). Um Outro Turismo é Possível (Other tourism is possible). Contexto, São Paulo: 83-88.

Bigné J.E., Sánchez I., 2001. Evaluación de la imagen de destinos turísticos: Una aplicación metodológica en la Comunidad Valenciana (Evaluation of the image of tourist destinations: A methodological application in the Valencian Community). Revista Europea de Dirección y Economía de la Empresa 10: 189-200.

Bigné J.E., Sanchez M.I., Sanchez J. 2001. Tourism image, evaluation variables and after purchase behavior: Inter-relationship. Tourism Management 22: 607-616.

Bordas E., Rubio M.L., 1993. La imagen turística de España: un modelo de gestión a largo plazo (The tourist image of Spain: A long-term management model). Información Comercial Española 722 (octubre): 107-118.

Cabrer Borrás B., Sancho Pérez A., Serrano Domingo G., 2001. Microeconometría y decisión (Microeconometrics and decision). Pirámide, Madrid.

Cánoves Valiente G.,Villarino Pérez M., Blanco-Romero A., De Uña Álvarez E., Espejo Marín C., 2014. Estrategias y productos en Catalunya, Galicia y Murcia (Strategies and products in Catalonia, Galicia and Murcia). Universidad de Valencia, Valencia.

Castrogiovanni A.C., 2007. Lugar, no-lugar y entre-lugar. Los ángulos del espacio (Place, non-place and between-place. The angles of space). Estudios y perspectivas en turismo 16(1).

Dazy F., Le Barzic J.F., 1996. L'analyse des données évolutives. Méthodes et applications. Éditions Technip, Paris.

Ferreira Lopes S.D., Rial Boubeta A., Varela Mallou J., 2010. Segmentación post hoc del mercado turístico español: Aplicación del análisis cluster en dos etapas (Post hoc segmentation of the Spanish tourism market: Application of the two-stage cluster analysis). Estudios y Prespectivas en Turismo 19(5): 592 - 606.

Gallarza M.G., García H.C., Saura I.G., 2002. Destination image. Towards a conceptual framework. Annals of Tourism Research 29(1): 56-78.

Hair J.F., Anderson R.E., Tatham R.L., Black W.C., 1999. Análisis Multivariante (Multivariate analysis). Pearson/Prentice-Hall, Madrid.
Johnson D.E., 2000. Métodos multivariados aplicados al análisis estadístico de datos. (Multivariate methods applied to statistical data analysis). Thomson-Paraninfo, Madrid.

Merinero R., Pulido J.A., 2009. Desarrollo turístico y dinámica relacional: metodología de análisis para la gestión activa de destinos turísticos (Tourism development and relational dynamics: Analysis methodology for the active management of tourist destinations). Cuadernos de Turismo 23: 173-194.

Morin E., 2000. Ciência com Consciência (Science with consciousness). Bertrand Brasil, Rio de Janeiro.

Panosso Netto A., 2007. Filosofía del turismo. Una propuesta epistemológica (Philosophy of tourism. An epistemological proposal). Estudios y Prespectivas en Turismo 16(4): 1-10.

Ortega Valcárcel J., 1998. El patrimonio territorial: el territorio como recurso cultural y económico (Territorial heritage: The territory as a cultural and economic resource). Ciudades 4: 33-48.

Pearce D., 2014. Destinos Turísticos: conceptos e implicaciones para su gestión en tiempos de cambio (Tourist destinations: Concepts and implications for its management in times of change). In: López Palomeque F., Cánoves Valiente G. (eds), Turismo y Territorio. Innovación, renovación y desafios. Tirant Humanidades, Valencia: 21-34.

Pérez López C., 2005. Métodos estadísticos avanzados con SPSS (Advanced Statistical Methods with SPSS). Thomson-Paraninfo, Madrid.

Picón E., Varela J., 2000. Segmentando mercados con análisis conjunto: una aplicación al sector turístico (Segmenting markets with joint analysis: An application to the tourism sector). Psicothema 12(2): 453-458.

Pillet Capdepón F., 2015. Del espacio geográfico al turismo como uso y disfrute del territorio comarcal: una reflexión teórica desde España (From geographic space to tourism as use and enjoyment of regional territory: A theoretical reflection from Spain). Revista de Geografia Norte Grande 62: 185-201.

Plan Nacional e Integral del Turismo (National and Integral Tourism Plan) (2012-2015) http:/ / www.minetur.gob.es/ turismo/es-es/documents/pnit_2012_2015_v2.pdf.

Rial A., García A., Varela J., 2008. Una aplicación metodológica para el estudio de la Imagen de Marca de un destino turístico (A methodological application for the study of the brand image of a tourist destination). Pasos. Revista de Turismo y Patrimonio Cultural 6: 1-10.

Rial A., Ferreira S.D., Varela J., 2010. Aplicação da Análise Conjunta no Estudo das Preferências Turísticas (Application of the joint analysis in the study of tourism preferences). Revista Portuguesa de Marketing 26.

Richards G., 2018. Cultural tourism: A review of recent research and trends. Journal of Hospitality and Tourism Management 36:12-21. doi.org/10.1016/j.jhtm.2018.03.005.

Rivas J., 2008. Estructura y economía del mercado turístico (Structure and economy of the tourist market). Septem ediciones, Oviedo.

Rodríguez P., Molina O., 2007. La segmentación de la demanda turística española (The segmentation of the Spanish tourist demand). Metodología de Encuestas 9: 57-92.

Uriel Jiménez E., Aldás Manzano E., 2005. Análisis Multivariante Aplicado (Applied multivariate analysis). Thomson-Paraninfo, Madrid.

Valls J.F., 1992. La imagen de marca de los países (The brand image of the countries). McGraw-Hill, Madrid.

Varela J., Picón E., Braña T., 2004. Segmentation of the Spanish domestic tourism market. Psicothema 16(1): 76-83. 
Varela J., García A., Manzano V., Rial A., 2006. Development of an index to assess the brand image of tourist destinations. Anales de Psicología 22: 155-160.
Wilson E., Hollinshead K., 2015. Qualitative tourism research: Opportunities in the emergent soft sciences. Annals of Tourism Research 54:30-47. doi.org/10.1016/j.annals.2015.06.001.

\section{Annexes}

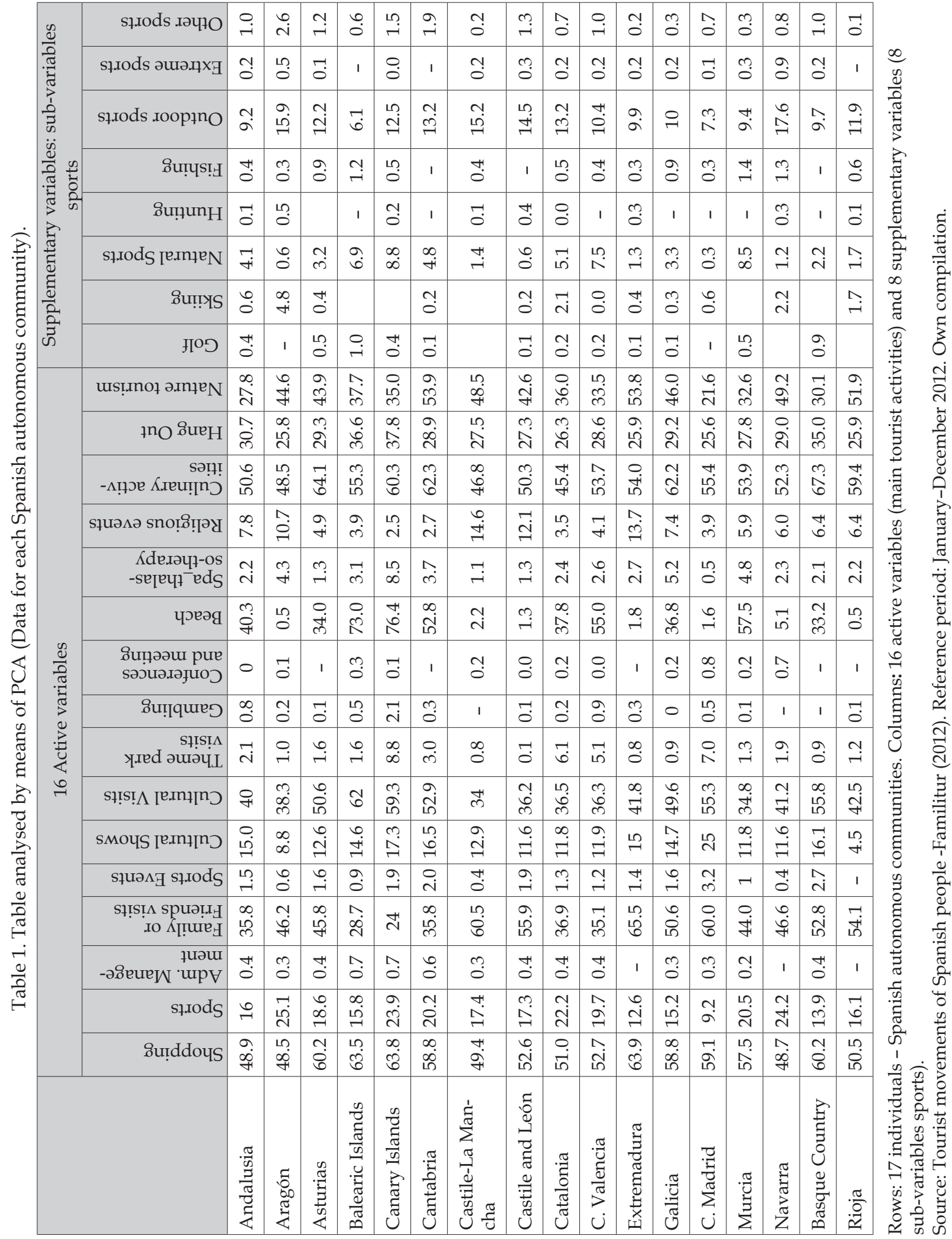


Table 2. Complete table of individual-factor coordinates.

\begin{tabular}{|l|c|c|c|r|r|}
\hline \multicolumn{1}{|c|}{ Individuals } & Distance to origin & Factor 1 & Factor 2 & Factor 3 & Factor 4 \\
\hline Andalusia & 7.625 & 0.095 & 0.732 & 1.392 & -1.586 \\
\hline Aragón & 14.558 & -2.720 & 2.219 & 0.275 & 0.182 \\
\hline Asturias & 5.140 & 0.235 & -0.806 & -1.214 & 0.614 \\
\hline Balearic Islands & 22.097 & 3.422 & 0.487 & -1.542 & 0.408 \\
\hline Canary Islands & 54.199 & 6.627 & 2.181 & 0.451 & -0.785 \\
\hline Cantabria & 11.248 & 2.051 & 0.073 & -1.362 & 1.476 \\
\hline Castile-La Mancha & 18.171 & -3.693 & 0.545 & 0.176 & -1.001 \\
\hline Castile and León & 10.587 & -2.689 & -0.224 & -0.197 & -1.289 \\
\hline Catalonia & 10.234 & -0.405 & 1.488 & 2.267 & 0.812 \\
\hline C. Valencia & 7.718 & 0.567 & 1.565 & 1.596 & -0.552 \\
\hline Extremadura & 15.322 & -2.020 & -1.642 & -1.656 & -0.841 \\
\hline Galicia & 6.173 & 0.075 & -0.825 & -1.602 & -0.190 \\
\hline C. Madrid & 41.131 & 1.046 & -5.519 & 2.942 & 0.707 \\
\hline Murcia & 8.140 & -0.572 & 1.097 & 0.287 & -0.404 \\
\hline Navarra & 13.267 & -1.515 & 1.011 & 0.478 & 2.509 \\
\hline Basque Country & 14.781 & 1.658 & -2.477 & -1.113 & -1.106 \\
\hline Rioja & 11.611 & -2.162 & 0.094 & -1.177 & 1.045 \\
\hline
\end{tabular}

Source: own study.

Table 3. Complete table of relative contributions.

\begin{tabular}{|l|c|c|c|c|c|}
\hline \multicolumn{1}{|c|}{ Individuals } & Distance to origin & Factor 1 & Factor 2 & Factor 3 & Factor 4 \\
\hline Andalusia & 7.625 & 0.001 & 0.070 & 0.254 & 0.330 \\
\hline Aragón & 14.558 & 0.508 & 0.338 & 0.005 & 0.002 \\
\hline Asturias & 5.140 & 0.011 & 0.126 & 0.287 & 0.073 \\
\hline Balearic Islands & 22.097 & 0.530 & 0.011 & 0.108 & 0.008 \\
\hline Canary Islands & 54.199 & 0.810 & 0.088 & 0.004 & 0.011 \\
\hline Cantabria & 11.248 & 0.374 & 0.000 & 0.165 & 0.194 \\
\hline Castile-La Mancha & 18.171 & 0.751 & 0.016 & 0.002 & 0.055 \\
\hline Castile and León & 10.587 & 0.683 & 0.005 & 0.004 & 0.157 \\
\hline Catalonia & 10.234 & 0.016 & 0.216 & 0.502 & 0.065 \\
\hline C. Valencia & 7.718 & 0.042 & 0.317 & 0.330 & 0.040 \\
\hline Extremadura & 15.322 & 0.266 & 0.176 & 0.179 & 0.046 \\
\hline Galicia & 6.173 & 0.001 & 0.110 & 0.416 & 0.006 \\
\hline C. Madrid & 41.131 & 0.027 & 0.741 & 0.210 & 0.012 \\
\hline Murcia & 8.140 & 0.040 & 0.148 & 0.010 & 0.020 \\
\hline Navarra & 13.267 & 0.173 & 0.077 & 0.017 & 0.475 \\
\hline Basque Country & 14.781 & 0.186 & 0.415 & 0.084 & 0.083 \\
\hline Rioja & 11.611 & 0.403 & 0.001 & 0.119 & 0.094 \\
\hline
\end{tabular}

Source: own study. 